\title{
Thematic Opinion
}

\section{Impacts of COVID-19 on Nepalese economy}

\author{
Satis Devkota \\ ${ }^{1}$ Division of Social Science, University of Minnesota-Morris, 600 East 4th Street, Morris, MN 56267, USA
}

Received: May 2 3, 2020; Accepted: June 14, 2020; Published: June 25, 2020

\begin{abstract}
Even though Nepal reported the first confirmed case of COVID-19 in late January 2020, Nepal was one of the least affected countries in South Asia until the end of April 2020. Lockdown and social distancing were implemented from the very beginning and people also contributed voluntarily with certain exceptions to that government's efforts. That has a positive effect on flattening the curves of COVID-19 affected people and the related death rates in Nepal. However, the macroeconomic consequences of the pandemic are pretty high for a remittance based small economy. This hardship is further escalated when the excessive inflow of the Nepali migrant workers from India carried and transmitted the virus to 1,811 people by June 1, 2020. Still, that number is not high if the government gets success to control the spread outright.
\end{abstract}

Keywords: COVID-19; economic impact; economic recovery; rural employment

सारांश: सबैभन्दा पहिलो कोभिड-१९ बाट प्रभावित व्यक्ति सन् २०२० को जनवरिमानै नेपालमा भेटिएको भएतापनि, सन् २०२० को अप्रिलको अन्त्य सम्मन पनि नेपाल यस भाइरस बाट सबैभन्दा कम प्रभावित दक्षिण एशीयाली मुलकहरु मध्ये एक थिया । नेपाल सरकारले यस रोगको बिष्वब्यापिकरण संगै बन्दाबन्दि र सामाजिक दूरी कायम राखु पर्ने कानून लगाएको थियो र यसको छिटपुट अबज्ञा भएको भएतापनि जनस्तरबाट प्राप्त ब्यापक सहयोग का कारण यो कानन प्रभाबकारी देखिएको थियो। यसले कभिड(१९ भाइरस फैलन बाट रोक्न निकै हदसम्म कामगरेको भएतापनि नेपाल जस्तो विप्रेषण आयमा आधारीत अर्थतन्त्र को समग्र आर्थिक सूचकाँकहरु मा भने यसले नकारात्मक प्रभाव पारेको थियो। यसले नेपाली जनजिबन र अर्थतत्त्रमा निम्त्याएको जटिलता भने भारत बाट अत्याधिक मात्रामा नेपाल फर्किएका वा फर्काइएका प्रबाशी नेपालीहरुले जुन १ सन् २०२० सम्ममा करिब १,६११ जनामा यो भाइरस सारिसकेको हुँदा अरु थपिन गएको छ। तर नेपाल सरकारले यसलाइ यही अबस्थामा रोक्न सक्दा यो सँख्या अत्याधिक भने होइन । 


\section{Introduction}

The COVID-19 outbreak was initiated from Wuhan, China, in December 2019 and it was announced as a pandemic on March 11, 2020, by the World Health Organization (WHO). In South Asia, Nepal reported the first confirmed case of COVID19 on January 24, 2020. As of June 1, 2020, Nepal has confirmed 1,811 cases and 8 deaths (JHU, 2020). Due to the lack of sufficient testing kits and limited availability of budget; the tracing, testing, and treating strategy has not been implemented in a very organized way in Nepal. The response on lockdown and social distancing were implemented from the very beginning and people also contributed voluntarily with certain exceptions to the government's efforts in lockdown and social distancing.

At the community level, enforcing lockdown and social distancing was a little problem due to the inward migration of Muslim Pilgrims during the time of Ramadan in certain districts of Nepal. Besides, thousands of Nepalese migrant workers in India either lost their jobs or were forcefully sent back in April and May 2020. Those Muslim Pilgrims and the immigrant workers are the majority of COVID-19 carriers in Nepal. Even after Ramadan, the Nepalese government decided to implement the international travel bans, lockdown, and social distancing until the middle June of 2020. That helped to keep the infected individuals in isolation, reduce the infection rates (R0 value) and flatten the curves of the total number of confirmed cases, hospitalizations, and deaths in Nepal. However, the danger of increasing the infection rate (R0) is not over yet. Real challenges such as limitations at the healthcare facilities, a lack of medical supplies to fight the virus, the existence of chronic poverty and hunger, issues of the urban slums, and lack of proper cleanliness at home, in the hospitals, and the workplaces are teasing the Nepalese policymakers.

\section{Economic Impact}

Because of the global economic fallout triggered by the COVID-19 pandemic, the South Asian economy is forecasted to shrink. The estimated growth rate for the region will fall to a range between 1.8 to 2.8 percent in 2020 , which is down by 4.5 to 3.5 percent from the previous projection made by the World Bank six months before (World Bank, 2020). In Nepal, growth is expected to fall to a range between 1.5 and 2.8 percent in the fiscal year $2020 / 21$. That is triggered by lower remittances, higher trade deficit, lower tourism, and many other disruptions caused by the COVID-19 outbreak (World Bank, 2020). A continuous outbreak of COVID-19 for a prolonged period would impact growth significantly with a further decline in construction, manufacturing, industrial production, and services. That could subdue the economic growth for the fiscal year 2021/2022 as well (World Bank, 2020).

That economic downturn could create multiple effects in our society. It reduces productivity, increases unemployment, reduces the average income of households, and enhances poverty, hunger, and malnutrition. Those all collectively affect aggregate demand and destabilize the global supply chain. That will further exert downward pressure on foreign currency holding that leads to the devaluation of Nepalese currency and inflation in the Nepalese economy. Besides, the economic downturn weakens the financial system, distorts the tax base, and weakens the government's capacity to finance for public infrastructures.

In that case, recovery is costly and a lengthy process. That will have severe implications for the poor and marginalized population in society for a longer period. It will also enhance inequalities, social crimes, depression, suicide, prostitution, insecurity, vulnerability, and marginalization. That may inflict the public health emergency from other aspects as well. Lockdown, social distancing, and isolation measures will not be effective if the problems of the poor and marginalized are not addressed timely. If the poor and vulnerable population in the country are not protected in the real sense and discriminated by gender, caste and ethnicity, country of origin, and their income level, sooner or later they might be translated into the pandemic bomb that can burst any time in the society. We know, viruses do not have boundaries, it can affect people of any class, wealth, ethnicity, or status, and public health is determined by the least common denominator. That means, if the poorest and most marginalized within a society are not protected then no one is safe.

Realizing this fact, India and Pakistan have announced an economic relief package (cash transfer program) in the recent past as a short-term measure to save their economy from the pandemic shock. That will help smooth consumption, and expand the ability of poor and vulnerable to utilize health care facilities at their difficulties. Cash transfers also help to prevent the poor and marginalized population in suffering from shocks of a pandemic. This helps to reduce inequality and other problems stated above and restores the demand side of the economy. Besides, it helps to enhance the individual's motivation to follow the rules of lockdown, social distancing, and isolation, and ultimately helps to flatten the curve. Hope, Nepal's government will learn the lesson from India and Pakistan and announce a similar economic rescue package to help the poor and marginalized population. In addition, 
the poor and vulnerable must get free testing, tracing, and treating facilities. That will save the lives of thousands of other people in the country.

\section{Economic Recovery Strategy}

As a medium-term plan for recovery, the government has to design innovative policies to enhance agricultural productivity and create thousands of new employment opportunities in rural agriculture. That can be done by implementing enterprise farming or leasehold farming techniques. In Nepal, every dollar increase in the agriculture sector GDP has a much larger effect in rural employment creation and poverty alleviation than the same dollar amount increase in the industrial sector until the country is promoted to the middle-income status. In the long-run, the increased productivity in agriculture might have multiplier effects in the other sectors of the economy. For Asia, the value of the multiplier is between 1.6 to 1.8 (Janvery \& Sadoulet, 2016). This means that every one dollar growth in agriculture induces another 60 to 80 cents growth in non-agriculture. That growth in non-agriculture will also create additional employment opportunities in Nepal. I believe that strategy could help to create millions of employment opportunities in the country. That can stop the migration of the workforce in Gulf countries and Malaysia.

\section{Ethical approval}

Not required given the nature of the article.

\section{Funder information}

No funding.

\section{Competing interests}

None declared.

\section{References}

Janvry AD, Sadoulet E. 2016. Development Economics: Theory and Practice. Routledge, 711 Third Avenue, New York, NY 10017. ISBN-13: 978-1138885318

JHU, 2020. COVID-19 Dashboard by the Center for Systems Science and Engineering (CSSE) at Johns Hopkins University. Johns Hopkins University, Maryland, USA. Data generated on June 1, 2020.

World Bank, 2020. South Asia Economic Focus, Spring 2020: The Cursed Blessing of Public Banks. Washington, DC: World Bank. 